\title{
X-linked Charcot-Marie-Tooth disease type 5
}

INSERM

\section{Source}

INSERM. (1999). Orphanet: an online rare disease and orphan drug data base. $\underline{X \text {-linked }}$ Charcot-Marie-Tooth disease type 5. ORPHA:99014

X-linked Charcot-Marie-T ooth disease type 5 is a rare, genetic, peripheral sensorimotor neuropathy characterized by an X-linked recessive inheritance pattern and the infancy- to childhood-onset of: 1) progressive distal muscle weakness and atrophy (first appearing and more prominent in the lower extremities than the upper) which usually manifests with foot drop and gait disturbance, 2) bilateral, profound, prelingual sensorineural hearing loss and 3) progressive optic neuropathy. Females are asymptomatic and do not display the phenotype. 